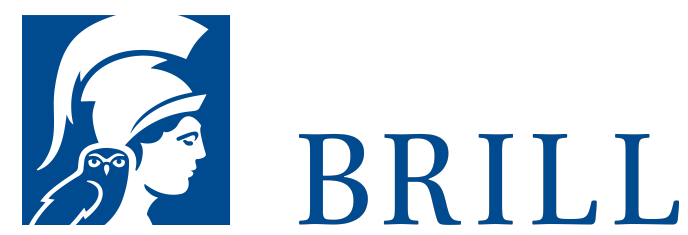

\title{
Poetische Dogmatik: Gotteslehre
}

Band 3: Bilder

Author: Alex Stock

Die Poetische Dogmatik ist zu ihrem siebten Band gelangt. Wie die Christologie sich an die Zahl der kanonischen Evangelien hielt, so wird die Gotteslehre sich an den entsprechenden Vorgaben des Glaubensbekenntnisses orientieren. Der vorliegende dritte Band bildet also ihren Abschluss. Wenn es im ersten Band darum ging, den vielfältigen Sitz im Leben des Redens von Gott zu erkunden, und im zweiten, die labyrinthische Sprachbewegung zu besprechen, die sich an den Namen heftet, so verspricht der Titel des dritten Anschaulichkeit. Es geht um die Sichtbarkeit (oder Unsichtbarkeit) des Unsichtbaren, um Vision und Visualisierung Gottes und den damit verbundenen Widerstreit. Das wird im ersten Teil des Bandes unter der Überschrift „Gottheit“, beim biblischen Bilderverbot beginnend, grundlegend verhandelt. Im zweiten und dritten Teil werden klassische Themen, die üblicherweise als Inbegriff abstrakter Spekulation gelten, die Lehre vom Hl. Geist und von der Dreifaltigkeit Gottes, ausdrücklich von der Bildseite her angegangen.

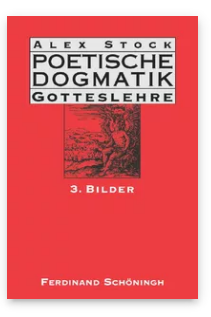

Pages: 449

Seiten

Language:

German

Subjects:

General,

Theology and

World

Christianity

Publisher: Brill |

Schöningh

Series:

Poetische

Dogmatik:

Gotteslehre,

Volume: 3

E-Book (PDF)

Released online:

29 Oct 2019

ISBN: 978-3-

657-76449-5

List price

USD \$131.00

Hardback

Publication date:

$25 \mathrm{Jul} 2007$

ISBN: 978-3-

506-76449-2

List price

USD \$131.00 
For more information see brill.com

Order information: Order online at brill.com +44330 333 0049 | customerservices@brill.com Submission information: brill.com/authors

Titles published by Brill | Fink, Brill | mentis or Brill | Schöningh: +49(o)715413279216| brill@brocom.de 